\title{
Prevalence of Trichinella spp. Infection in Large Wild Carnivore Species from Romania between Jan 2014 and July 2015
}

\author{
Ionuț MARIAN ${ }^{1 *}$, Andrei Daniel MIHALCA ${ }^{1}$, Călin Mircea GHERMAN ${ }^{1}$ \\ ${ }^{1}$ University of Agricultural Sciences and Veterinary Medicine Cluj-Napoca, Calea Mănăștur 3-5, 400372, \\ Cluj-Napoca, Romania \\ *Corresponding author: klis87ionut@yahoo.com
}

Bulletin UASVM Veterinary Medicine 72(2) / 2015,

Print ISSN 1843-5270; Electronic ISSN 1843-5378

DOI:10.15835/buasvmcn-vm: 11631

\begin{abstract}
Trichinella spp. is a widely distributed nematode species affecting a large variety of hosts. Two major foci are identified in the natural cycle of the parasite: synanthropic and sylvatic. The sylvatic cycle includes two groups of animals: carnivores and omnivores. The carnivorous cycle of Trichinella involves large and small species as the bear, wolf, golden jackal, wildcat, lynx and mustelids, many of them common in Romania. The present study aimed to update the data on the prevalence of Trichinella spp. infection in large carnivores from Romania between 2014 and 2015, using the artificial digestion method. Out of 67 examined cadavers, 54 were golden jackals, 5 wolves, 5 wildcats and 3 Eurasian lynxes. All species were infected with Trichinella spp. and the prevalence was $40.0 \%$ in wolf, $33.3 \%$ in wildcat, $53.7 \%$ in golden jackal and $66.6 \%$ in Eurasian lynx. These data demonstrate that wild carnivores remain important reservoirs for Trichinella in nature in Romania.
\end{abstract}

Keywords: carnivores, prevalence, Romania, Trichinella spp.

\section{ABBREVIATIONS:}

spp. species; EC, European Comission; CI, confidence interval

\section{INTRODUCTION}

Romania's Carpathians are one of the last European bastions for wild carnivores. At least two large carnivore species, the wolf (Canis lupus) and Eurasian lynx (Lynx lynx), live in mountainous regions of the country recording the highest density known in Europe, except for the European part of the Russian Federation (Kelemen and Selaru, 2015). Their populations are estimated at 2500 wolves and between 1200 to 1500 lynxes (Sin et al., 2014). Besides these two species, the golden jackal (Canis aureus) spreads rapidly across the country, occupying various ecosystems in Eastern, Southern, and Western Romania, its population being estimated at over 6400 individuals in 2013 (Papp et al., 2014). In addition, the wildcat remains a constant presence in the sylvatic ecosystems of the country, its population being evaluated at 10000 individuals (Yamaguchi et al., 2015). All these species are involved in the sylvatic cycles of Trichinella species in Romania, T. britovi being the only species previously identified in these hosts (Blaga et al., 2008, 2009).

However, the importance of wild carnivores in the epidemiology of Trichinella infections in wildlife is poorly investigated.

The aim of the present work is to determine the recent prevalence of Trichinella spp. infection in these species in Romania, between 2014 and 2015.

\section{MATERIALS AND METHODS}

Muscle samples from specific collection sites were collected from cadavers of four wild carnivore species hunted or found dead in hunting 
Tab. 1. The frequency, prevalence and 95\% CI of Trichinella spp. infection in wild carnivores

\begin{tabular}{cccc}
\hline Species & Frequency & Prevalence (\%) & $95 \%$ CI \\
\hline Wild cat & $2 / 6$ & 33.3 & $4.3-77.7$ \\
\hline Wolf & $2 / 5$ & 40.0 & $5.2-85.3$ \\
\hline Golden Jackal & $29 / 54$ & 53.7 & $39.6-67.4$ \\
\hline Lynx & $2 / 3$ & 66.6 & $9.4-99.2$ \\
\hline
\end{tabular}

lands all over the country, between January 2014 and July 2015. A total number of 67 cadavers were examined, of which 54 were golden jackals (Canis aureus), 5 wolves (Canis lupus), 5 wildcats (Felis silvestris) and 3 Eurasian lynxes (Lynx lynx). The Golden Jackals have originated in 13 eastern, southern and western Romanian counties (Botoșani, Buzău, Brăila, Tulcea, Ialomița, Ilfov, Giurgiu, Teleorman, Olt, Vâlcea, Dolj, Gorj, and Timiș). The wolves were hunted in hunting areas from the center of The Transylvanian plateau. The wild cats were collected in three counties located in southeastern and northern Romania respectively (Buzău, Tulcea, and Maramureș) and all lynxes originated from Transylvania. All muscle samples were examined using artificial digestion technique described in Commission Regulation (EC) No 2075/2005.

\section{RESULTS AND DISCUSSION}

The prevalence of Trichinella spp. infection ranged between 33.3\% (IC 95\%: 4.3 - 77.7) recorded in wild cat and 66.6\% (IC 95\%: 9.4 99.2) in Eurasian lynx (table 1).

Trichinella infection in wild carnivores remains a subject of interest worldwide. The data previously obtained in Romania and across Europe confirm this fact. Studies performed between 2000 and 2005 in the same area of Romania revealed similar values of prevalence in these species: $14 \%$ in wild cat, $31 \%$ in wolf and $60 \%$ in Eurasian lynx (Blaga et al., 2009). In Serbia, 7 out of 13 (53.8\%) golden jackals, and $49.5 \%$ of the examined wolves were infected with Trichinella spp. (Zivojinovic et al., 2013; Teodorović et al., 2014). Sylvatic Trichinella spp. infection in Finland during 1999-2005 recorded high prevalence in wolf (39.2\%) and Eurasian lynx (45.5\%) (Airas et al., 2010). The prevalence of infected wolves was $31 \%$ in Croatia, $69.7 \%$ in Latvia and $12.8 \%$ in north-western Spain (Beck et al., 2009; Bagrade et al., 2009; Segovia et al., 2001). The highest prevalence of Trichinella spp. infection in wolves was detected in European Russia between 1998 and 2000 (97.5\%) (Pozio et al., 2001). In Estonia, the most important reservoirs of Trichinella in nature were the lynx and the wolf, among other species, the prevalence being $50 \%$ in wolf during the 2000/2001 and 2003/2004 hunting seasons (Järvis et al., 2001; Moks et al., 2006). Moreover, the mustelids, representing another important group of wild carnivores, are also common hosts of Trichinella infection (Pozio et al., 2001; Airas et al., 2010; Oltean et al., 2014; ).

\section{CONCLUSION}

All these results demonstrate that wild carnivores play an important reservoir role in the sylvatic cycle of Trichinella in Europe.

\section{REFERENCES}

1. Airas N, Saari S, Mikkonen T, Virtala AM, Pellikka J, Oksanen A, Isomursu M, Kilpelä SS, Lim CW, Sukura A (2010). Sylvatic Trichinella spp. infection in Finland. J Parasitol. 96(1):67-76.

2. Bagrade G, Kirjusina M, Vismanis K, Ozolins J (2009). Helminth parasites of the wolf Canis lupus from Latvia. J Helminthol. 83(1):63-8.

3. Beck R, Beck A, Kusak J, Mihaljević Z, Lucinger S, Zivicnjak T, Huber D, Gudan A, Marinculić A (2009). Trichinellosis in wolves from Croatia. Vet Parasitol. 159(3-4):308-11.

4. Blaga R, Gherman C, Cozma V, Zocevic A, Pozio E, Boireau $P$ (2009). Trichinella species circulating among wild and domestic animals in Romania. Vet Parasitol 159(3-4):21821.

5. Blaga R, Gherman C, Seucom D, Cozma V, Boireau P (2008). First identification of Trichinella sp. in golden jackal (Canis aureus) in Romania. J Wildl Dis 44(2):457-9.

6. Commission Regulation (EC) No 2075/2005 of 5 December 2005 laying down specific rules on official controls for Trichinella in meat (Text with EEA relevance) (http://eur-lex.europa.eu/LexUriServ/LexUriServ.do?uri $=0 J: L: 2005: 338: 0060: 0082: E N: P D F)$

7. Ionescu O (1993). Wildcat in Romania. In Seminar on the biology and conservation of the wildcat (Felis silvestris), Nancy, France, 23-25 September 1992. Council of Europe, Strasbourg, 57-58. 
8. Järvis T, Miller I, Pozio E (2001). Epidemiological studies on animal and human trichinellosis in Estonia. Parasite. 8(2 Suppl): S86-7.

9. Kelemen A, Şelaru N (2015). The Evolution and the Management of Large Carnivores from the Hunters Perspective in Romania. Available at: http://ec.europa.eu/ environment/nature/conservation/species/carnivores/ pdf/18_Kelemen_LC_Romania\%20_Hunters_Perspective. pdf. Accessed 2015 Aug. 25.

10. Moks E, Jõgisalu I, Saarma U, Talvik H, Järvis T, Valdmann $\mathrm{H}$ (2006). Helminthologic survey of the wolf (Canis lupus) in Estonia, with an emphasis on Echinococcus granulosus. J Wildl Dis. 42(2):359-65.

11. Papp CR, Banea OC, Szekely-Sitea AI (2014). Applied ecology and management aspects related to the golden jackal specific ecological system in Romania. Acta Musei Maramorosiensis IX

12. Pozio E, Casulli A, Bologov VV, Marucci G, La Rosa G (2001). Hunting practices increase the prevalence of Trichinella infection in wolves from European Russia. J Parasitol. 87(6):1498-501.

13. Segovia JM, Torres J, Miquel J, Llaneza L, Feliu C (2001). Helminths in the wolf, Canis lupus, from north-western Spain. J Helminthol. 75(2):183-92.
14. Sin T, Chiriac S, Pop IM, Pătrașcu LM, Gazzola A, Rîşnoveanu G (2014). Long-term fluctuation of Romanian Large Carnivore populations: a multifactor analysis. Int Sci Conf "European large carnivores: problems of smallsized populations, study on reproduction, and challenges of reintroduction programs", Krasny Bor terrain, Dobroplyosy village, Verkhnedvinsk district, Belarus; $09 / 2014$

15. Teodorović V, Vasilev D, Ćirović D, Marković M, Ćosić N, Djurić S, Djurković-Djaković O (2014). The wolf (Canis lupus) as an indicator species for the sylvatic Trichinella cycle in the Central Balkans. J Wildl Dis. 50(4):911-5.

16. Yamagu chi N, Kitchener A, Driscoll C, Nussberger B (2015). Felis silvestris. The IUCN Red List of Threatened Species. Version 2015.2. <www.iucnredlist.org>. Downloaded on 25 August 2015.

17. Zivojinovic M, Sofronic-Milosavljevic Lj, Cvetkovic J, Pozio E, Interisano M, Plavsic B, Radojicic S, Kulisic Z (2013). Trichinella infections in different host species of an endemic district of Serbia. Vet Parasitol. 194(2-4):136-8. 